\title{
Prevalence of dental malocclusions in 12-year-old schoolchildren from Cuenca, Ecuador.
}

\section{Santiago Coello-Vásquez ${ }^{1}$, Alberto Alvarado-Cordero ${ }^{1}$, María Augusta Delgado-López ${ }^{1} \&$ Luisa Salinas-Abarca ${ }^{1}$}

Abstract: The aim of this paper was to determine the prevalence of malocclusions in 12-year-old schoolchildren from Cuenca, Ecuador. A cross-sectional study was carried out, including a clinical examination of 181 schoolchildren aged 12 years, who were randomly selected from the schoolchildren population. We assessed the presence of malocclusions using the Angles classification. The analysis was performed in the program Epilnfo 7.2. The majority of the patients presented malocclusions (91.7\%). There is no significant difference between public and private schools and the male sex was slightly more affected. There was a predominance of the Class II division 1 (30.4\%), followed by Class III (25.4\%), and Class I (24.9\%), with the lowest prevalence reported for Class II division 2 (11\%). A high rate of malocclusion was found in in 12-year-old schoolchildren from Cuenca, Ecuador, in both males and females. The dominant malocclusion in this study was Class II division 1.

Keywords: Prevalence, malocclusion, epidemiology

\section{INTRODUCTION}

Malocclusion has been classified in multiple ways, but to differentiate a malocclusion it is necessary to know the meaning of normocclusionp; Moyers refers to this when there is a normal molar, canine and skeletal relationship, and an absence of diastemas, crowding, crossbites or open bites (Moyers, 1988).

The World Health Organization (WHO) considers malocclusion as a disease, because it constitutes an aggravating factor for oral health, since it hinders proper oral hygiene, resulting in the accumulation of bacterial plaque and consequently the appearance of caries, gingivitis or periodontitis (Fernández et al., 2003; Salgado et al., 2017).

Malocclusions refer to any variation in the development and growth of the maxillary bones during childhood and adolescence, which leads to an abnormal occlusal relationship between the arches. This can cause alterations in oral function such as: poor mastication, speech difficulties, undesirable development of the jaws, and temporomandibular alterations, even impacting facial aesthetics (Zhifei et al., 2016; Ruiz et al., 2015; Jerez et al., 2014).

Occlusions can be altered by different factors, within which two main components are defined: a genetic predisposition and exogenous or environmental factors. An interrelation of these factors can exist, overlapping one cause on another, which will make its diagnosis difficult.
INT J MED

Affiliations: ${ }^{1}$ Universidad Católica de

Cuenca - Sede Azogues, Ecuador.

Corresponding author: María

Augusta Delgado-López. Dirección: Av 16 de abril, Azogues, Ecuador. Phone: +593998078203 .

E-mail: madelgadol@ucacue.edu.ec

Receipt:

$04 / 26 / 2018$

Revised:

$05 / 19 / 2018$

Acceptance:

$05 / 29 / 2018$

Online:

$08 / 30 / 2018$
Conflict of interests: None.

Ethics approval: Universidad Católica de Cuenca.

Funding: None.

Authors' contributions: All authors carried out the entire study.

Acknowledgements: None.

doi: $10.32457 / \mathrm{ijmss.2018.004}$. 
The most studied etiological factors as a cause of this alteration are the presence of oral parafunctions, loss of space due to dental caries, and the premature loss of teeth, among others (Espinal et al., 2016; Murrieta et al., 2009; Carrillo et al., 2016; Ramírez et al., 2012).

It is reported that the prevalence of malocclusions worldwide is high, ranging from $65 \%$ to $89 \%$. Latin America is not the exception, according to the Pan American Health Organization (PAHO), as the prevalence of this pathology exceeds $80 \%$. As a result, the WHO states that malocclusions take the third place among pathologies that affect oral health (Ramirez et al., 2012; Fajardo \& González, 2016; Fundagul et al., 2015).

There are many ways to classify malocclusion; however, in the present study, the Angle classification was used. In 1899, Angle devised a fairly simple and universally accepted scheme; this author introduced the term "Class" to name different mesiodistal relationships of teeth, dental arches and jaws, which depend on the sagittal position of the first permanent molars; these were considered fixed points of reference in the cranial facial architecture. This author divided the malocclusions into three major groups: Class I, Class II and Class III. This classification evaluates the position of the mesiobuccal cusp of the first upper molar and its relationship with the mesiobuccal groove of the lower first molar (Aguilar \& Taboada, 2013).

The aim of this paper was to determine the prevalence of malocclusions in 12-year-old schoolchildren Cuenca, Ecuador

\section{MATERIALS AND METHODS}

This was a cross-sectional study, with a population consisting of 181 12-year-old schoolchildren enrolled in the educational institutions of the San Sebastián urban parish of the city of Cuenca-Ecuador in 2016.

In order to comply with ethical and legal aspects, signed consent from the parents accepting the examination, along with the assent of the child, were obtained.

The clinical examination and data collection was carried out in an environment of good illumination, the technique used in this investigation was clinical observation, and the instrument for data collection was the clinical-epidemiological record provided by the Catholic University of

\section{TABLE 1. Sociodemographic distribution of 12-year-old}

schoolchildren

\begin{tabular}{lcccccc}
\hline & \multicolumn{2}{c}{ Public } & \multicolumn{2}{c}{ Private } & \multicolumn{2}{c}{ Total } \\
\multicolumn{1}{c}{ Sex } & $\mathrm{n}$ & $\%$ & $\mathrm{n}$ & $\%$ & $\mathrm{n}$ & $\%$ \\
\hline Female & 58 & 38.9 & 18 & 56.3 & 76 & 42 \\
Male & 91 & 61.1 & 14 & 43.8 & 105 & 58 \\
Total & 149 & 100 & 82 & 100 & 181 & 100 \\
\hline
\end{tabular}

Cuenca. In addition, buccal mirrors, a periodontal probe, masks, gloves, fields and disposable caps were used. The type of occlusion was established based on the Angle classification.

After the data collection, they were entered into the Epi-Info 7.2 software, for subsequent tabulation and to obtain the final results.

\section{RESULTS.}

The study sample of 181 children included schoolchildren of both sexes and school levels, with different types of academic management from the San Sebastián urban parish (Cuenca, Ecuador). The characterization of the participants is shown in Table 1.

In total, $91.7 \%$ of schoolchildren presented malocclusion, with $89.5 \%$ in females and $93.3 \%$ in males ( $p=0.35)$. In public school this was $92 \%$ and in private schools it was $91 \%(p=0.81)$.

It can be seen that the molar ratio that presented with the highest prevalence on both the right and left 
TABLE 2. Frequency of molar relation ship

\begin{tabular}{ccccc}
\hline & Left & & \multicolumn{2}{c}{ Right } \\
& $\mathrm{n}$ & $\%$ & $\mathrm{n}$ & $\%$ \\
\hline Class I & 85 & 47 & 87 & $\mathbf{4 8}$ \\
Class II & 32 & 29 & 49 & 27 \\
Class III & 38 & 21 & 39 & 22 \\
N.A & 6 & 3 & 6 & 3 \\
Total General & 181 & 100 & 181 & 100 \\
\hline
\end{tabular}

TABLE 3. Malocclusion frequency according to angle clasification

\begin{tabular}{lcccccc}
\hline & \multicolumn{2}{c}{ Male } & \multicolumn{2}{c}{ Female } & \multicolumn{2}{c}{ Total } \\
\hline & $\mathrm{n}$ & $\%$ & $\mathrm{n}$ & $\%$ & $\mathrm{n}$ & $\%$ \\
\hline Normocclusion & 8 & 10.5 & 7 & 6.7 & 15 & 8.3 \\
Class I & 13 & 17.1 & 32 & 30.5 & 45 & 24.9 \\
Class II-1 & 27 & 35.5 & 28 & 26.7 & 55 & 30.4 \\
Class II-2 & 10 & 13.2 & 10 & 9.5 & 20 & 11 \\
Class III & 18 & 23.7 & 28 & 26.7 & 46 & 25.4 \\
Total & 76 & 100 & 105 & 100 & 181 & 100 \\
\hline
\end{tabular}

side, was Class I, while Class III occurred less frequently bilaterally (Table 2). There is a higher frequency of Class II division 1 in men ( $p=0.39$, Table 3$)$.

\section{DISCUSSION}

In the present study, it was determined that the majority of patients presented malocclusion. This result is similar to that of Murrieta et al. (2017)with 96\%, Burgos et al. (2014) with 96.2\%, Pincheria et al. (2016) with 91.3\%, Aliaga et al. (2011) with 86.5\%, Fajardo et al. (2016) with $85 \%$ and Salgado et al. (2017) with an $88 \%$ prevalence of malocclusion. All of these results may vary according to the number of students analyzed, the difference in data recording methods, the different ages of the population studied, and the region in which the research was conducted, among others.

Regarding the incidence of malocclusions according to sex, in the study conducted by Arocha et al. (2016) in a population of 150 children in Santiago de Cuba, the male sex predominated; also, authors like Taboada et al. (2011), Aguilar et al.,(2013), and Ramírez et al. (2012) conducted studies in schoolchildren from different Mexican regions, obtaining a higher prevalence of malocclusions for this sex, coinciding with this study. On the contrary, in studies carried out by Zapata et al. (2014)and Montiel et al. (2004), a higher prevalence was reported for females.

In relation to the prevalence of malocclusions according to the type of school management, the study conducted by Fajardo et al. (2016) in a population of 252 schoolchildren, reported a greater number of affected schoolchildren for fiscal schools.

It was determined that Class II division 1 occurred more frequently, being higher than the rates reported for Nepalese children (Singh \& Sharm, 2014), adolescents in Lima (Zapata et al., 2014), and Libyan schoolchildren 
(Bugaighis \& Karanth, 2013). However, Fundagul et al. (2015) in the city of Kirikale-Turkey found that Class II division 1 malocclusion was more common in their population, coinciding with this study.

One out of four schoolchildren had Class III, which was similar to studies conducted by Salgado et al. (2017) and Ruiz et al.(2015), while Medina et al. (2010) and Arroyo \& Morera (2012) obtained lower proportions. The frequency of Class I malocclusion was lower in studies conducted by Bugaighis et al. (2013), with similar results for Medina et al. (2010) and Arroyo \& Morera (2012) Class II division 2 occurred less frequently; however, it is superior to the results of studies conducted by Fundagul et al. (2015), (Zapata et al., 2014) and (Singh \& Sharm, 2014).

\section{CONCLUSION}

The prevalence of malocclusions found in schoolchildren was high, with no differences by sex or school dependency. Angle Class II malocclusion was present in schoolchildren of both sexes.

\section{REFERENCES}

Aguilar N, Taboada 0. Frecuencia de maloclusiones y su asociación con problemas de postura corporal en una población escolar del Estado de México. Bol. Med. Hosp. Infant. Mex. 2013; 70(5):364-371.

Aliaga A, Mattos M, Aliaga R, Del Castillo C. Maloclusiones en niños y adolescentes de caseríos y comunidades nativas de la Amazonía de Ucayali, Perú. Rev Perú Med Exp Salud Pública. 2011;28(1):87-91.

Arocha A, Aranda M, Pérez Y, Granados A. Maloclusiones y hábitos bucales deformantes en escolares con dentición mixta temprana. MEDISAN. 2016; 20(4):426-32.

Arroyo Y, Morera H. Maloclusiones en niños de 8 a 12 años y la percepción de los padres de familia de la necesidad de una interconsulta con el ortodoncista a temprana edad. Re Cient Odontol. 2012; 8(2):19-24.

Bugaighis I, Karanth D. The prevalence of malocclusion in urban Libyan schoolchildren. J Orthod Sci. 2013;2(1):1-6.

Burgos D. Prevalencia de Maloclusiones en Niños y Adolescentes de 6 a 15 Años en Frutillar, Chile. Int J Odontostomat. 2014; 8(1):13-9.

Carrillo M, Tello G, Navarrete N. Relación de la succión no nutritiva con la maloclusión en niños ecuatorianos. Odontología. 2016;18(1):13-19.

Espinal G, Muñoz A, Flores L, Ponce M, Nava J, González J. Frecuencia de maloclusiones en las clínicas Odontopediátricas de la Universidad de Antioquia, Colombia, y de la Universidad Autonoma San Luis Potosí, México. Rev Nac Odontol. 2016; 12(22):59-66.

Fajardo J, González L. Prevalencia de Maloclusiones Dentales en escolares de 12 años en Monay- Cuenca 2016. Odontol Activa Rev Cient. 2016; 1(2): 23-28.
Fernández FJ, López JM, Vallejo E. Prevención de las maloclusiones. Gaceta Dental: Industria y Profesiones. 2003;(134):66-80.

Fundagul B, Ibrahim E, Ahmet A. Malocclusion prevalence and orthodontic treatment need in central Anatolian adolescents compared to European and other nations' adolescents. Dental Press J Orthod. 2015; 20(6):75.81.

Jerez E, Salas M, Simancas Y, Romero Y. Prevalencia de maloclusiones en niños del jardín de infancia de la escuela bolivariana "Juan Ruiz Fajardo". Acta Bioclinica. 2014; 4(8):5469.

Maryam A, Kamran B, Behnam H, Reza T, Hossein M. Prevalence of malocclusion among Iranian children: A systematic review and meta-analysis. Dent Res J (Isfahan). 2016;13(5):387-395.

Medina C. Prevalencia de maloclusiones dentales en un grupo de pacientes pediátricos. Acta Odontol Venez. 2010;48(1):94-9.

Montiel M. Frecuencia de maloclusiones y su asociación con hábitos perniciosos en una población de niños mexicanos de 6 a 12 años de edad. Rev ADM. 2004;61(6):209-14.

Moyers RE. Handbook of orthodontics, 4th ed. Chicago: Year Book, 1988.

Murrieta J, Cruz P, López J, Mrques M, Zurita V. Prevalencia de maloclusiones dentales en un grupo de adolescentes mexicanos y su relación con la edad y el género. Acta Odontol Venez. 2007; 45(1):74-8.

Murrieta J, Arrieta C, Juárez L, Linares C, González M, Meléndez A. Prevalencia de maloclusiones en un grupo de estudiantes universitarios mexicanos y su posible asociación con la edad el sexo y el nivel socioeconómico, 2009. Rev Fac Odontol Univ Antioq 2012; 24(1):121-32.

Pincheira C, Thiers S, Bravo E, Olave H. Prevalencia de Maloclusiones en Escolares de 6 y 12 Años de Choshuenco Neltume, Chile. Int J Med Surg Sci. 2016;3(2):829-37.

Ramírez J, Rueda M, Morales M, Gallegos A. Prevalencia de caries dental y maloclusiones en escolares de Tabasco, México. Horiz Sanit. 2012; 11(1): 13-23.

Ruiz A, Collante C, Guiglione M, Palcikwoski L. Prevalencia de maloclusiones en pacientes del servicio de ortodoncia de la Facultad de Odontología UNNE 2013. Rev Fac Odontol. 2015; 8(1):21-25

Salgado E, Villevicencio E, Ramos R. Prevalencia de maloclusiones en escolares de 12 años pertenecientes a la parroquia Gil Ramirez Dávalos (Cuenca) Ecuador. Revista Evidencias Odontologicas. 2017;1(3).

Singh VP, Sharma A. Epidemiology of malocclusion and assessment of orthodontic treatment need for nepalese children. Int Sch Res Notices. 2014;2014:1-4.

Taboada 0, Torres A, Cazares E, Orozco L. Prevalencia de maloclusiones y trastornos del habla en una población preescolar del oriente de la Ciudad de México. Bol Med Hosp Infant Mex. 2011; 68(2): 425-30.

Zapata M, Lavado A, Anchelia S. Hábitos bucales y su relación con maloclusiones dentarias en niños de 6 a 12 años. KIRU. 2014; 11(1):16-24.

Zhifei Z, Fen L, Shuning S,Linjuan S, Lei S, Xiaojing W. Prevalence of and factors affecting malocclusion in primary dentition among children in Xi'an, China. BMC Oral Health. $2016 ; 16(1): 90$. 